http://kitaibelia.unideb.hu/

ISSN 2064-4507 (Online) • ISSN 1219-9672 (Print)

(C) 2015, Department of Botany, University of Debrecen, Hungary

21 (1): 148-158.; 2016

DOI: $10.17542 / 21.148$

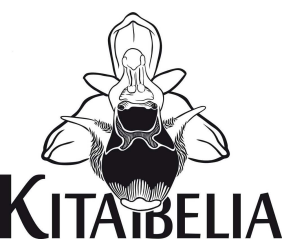

\title{
A 2015-ös év algája szavazás jelöltjei
} B-BÉres Viktória1*, NAGY-LÁSZló Zsolt², T-KrASZnAI Enikő1, STENGER-KovÁcs Csilla²,
BARRETo Sára ${ }^{3}$, KISS Gábor ${ }^{4}$, BuCZKó Krisztina ${ }^{5}$ \& ABONYI András ${ }^{6}$

(1) Hajdú-Bihar Megyei Kormányhivatal, Környezetvédelmi és Természetvédelmi Főosztály, Környezetvédelmi Mérőközpont, H-4025 Debrecen, Hatvan u. 16.; beres.viktoria@gmail.com

(2) Pannon Egyetem, Limnológia Intézeti Tanszék, H-8200 Veszprém, Egyetem u. 10.

(3) Pest Megyei Kormányhivatal, Környezetvédelmi és Természetvédelmi Főosztály, Környezetvédelmi Mérőközpont, H-1072 Budapest, Nagy Diófa u. 10-12.

(4) Fejér Megyei Kormányhivatal, Környezetvédelmi és Természetvédelmi Főosztály, Környezetvédelmi Mérőközpont, H-8000 Székesfehérvár, Hosszúsétatér 1.

(5) Magyar Természettudományi Múzeum, H-1083 Budapest, Ludovika tér 2-6.

(6) MTA-PE Limnoökológiai Kutatócsoport, H-8200 Veszprém, Egyetem u. 10.

\section{The Algae of the Year 2015 - Candidates of the election}

Abstract - While science-based education is widespread for macroscopic flora and fauna, the microscopic world has received much less attention. In 2015, having the aim of establishing a tradition, the Phycological Forum announced its first "Alga of the Year" in form of an online voting. The three candidates of algae were Didymosphenia geminata, Haematococcus pluvialis and Prymnesium parvum, from which the Haematococcus pluvialis received the overwhelming majority of votes. Introducing the ecological and economical aspects and distribution of the candidate taxa in Hungary, we aimed at to stress that there is a high educational potential of microscopic life. Furthermore, our study draws the attention to the fundamental role of algae in aquatic ecosystems, stressing their importance in maintaining life.

Keywords: Haematococcus pluvialis, Phycogeography, Phycology

Összefoglalás - Míg a szabad szemmel látható állat-, illetve növényvilággal kapcsolatos ismeretterjesztés széleskörűvé vált, addig a mikroszkopikus világ tudományos igényű ismeretterjesztő bemutatására kevés példát találni. Hagyományteremtő céllal 2015-ben első alkalommal hirdette meg az Algológus Fórum az „Év Algája” internetes szavazást. A végső szavazásra javasolt három algafaj a Didymosphenia geminata, Haematococcus pluvialis és Prymnesium parvum voltak, melyek közül a Haematococcus pluvialis fajra érkezett a szavazatok döntő többsége. A három faj ökológiai és gazdasági vonatkozásainak, valamint hazai elterjedésük bemutatásán keresztül kívánjuk megmutatni, hogy a mikroszkopikus világ képviselői is kellően színesek és érdekesek lehetnek ahhoz, hogy nagyobb teret kapjanak a tudományos ismeretterjesztésben. Tanulmányunk felhívja a figyelmet az algák vízi ökoszisztémákban betöltött alapvető szerepére, esetleges gazdasági jelentőségükre, valamint a földi élet fenntartásában nélkülözhetetlen szerepükre.

Kulcsszavak: algológia, fikogeográfia, Haematococcus pluvialis 


\section{Az „Év Algája” szavazás történeti előzményei}

$\mathrm{Az}$ „Év Algája” szavazás igénye a 2012-ben megalakult Algológus Fórum (továbbiakban $\mathrm{AF}$ ) által szervezett első Algológiai Találkozó és Továbbképzés (továbbiakban ATT) keretében merült fel. Az AF kitűzött célja, hogy az algológia területéhez kapcsolódóan szakmai programokat szervezzen és segítse a tudományos kommunikációt, melynek elérésére szakmai blogot hozott létre [1]. Az első szavazást 2015-ben, a szakmai és infrastrukturális háttér kialakítását követően hirdette meg. A szavazásra bocsátott algafajok kiválasztása a hazai algológus közösség közremúködésével, az általuk ajánlott fajok listáján alapult. Az algológusok tapasztalataik, elméleti és gyakorlati ismereteik szerint olyan algafajokat javasoltak, melyek elsősorban nem az „esztétikus” külső formavilágot veszik alapul, hanem olyan egyéb tényezőket is, mint például (i) ökológiai jelentőségük (ritkaság, vízvirágzások, vízszíneződések előidézése); (ii) esetleges gazdasági hasznuk (táplálék kiegészítőként, kozmetikai iparban, gyógyászatban történő használat); (iii) esetleges gazdasági káruk (megbetegedések előidézése, ivó-, itató-, fürdővizek minőségi romlása); vagy amelyeknek (iv) aktuális invázióbiológiai vonatkozásuk van.

A szakmai körből javasolt 11 taxon közül az első három legtöbb szavazatot kapott fajt hirdettük meg a 2015-ös „Év Algája” szavazáson; ezek a Didymosphenia geminata (Lyngbye) Mart. Schmidt, Haematococcus pluvialis Flotow és Prymnesium parvum N. Carter. voltak. Kezdeményezésünk minél szélesebb körű kiterjesztéséhez, a szakmai fórumokon túl e-mail formájában rövid ismertetőt küldtünk szét alap- és középfokú oktatási intézmények vezetőinek, titkárságainak, ill. ahol ismert volt, szaktanárainak. A beérkezett több mint 100 szavazat döntő hányadát (>50\%) egyetlen faj, a Haematococcus pluvialis zöldalgafaj szerezte meg.

\section{Az „Év Algájának” jelölt fajok 2015-ben}

Didymosphenia geminata (Lyngbye) Mart. Schmidt
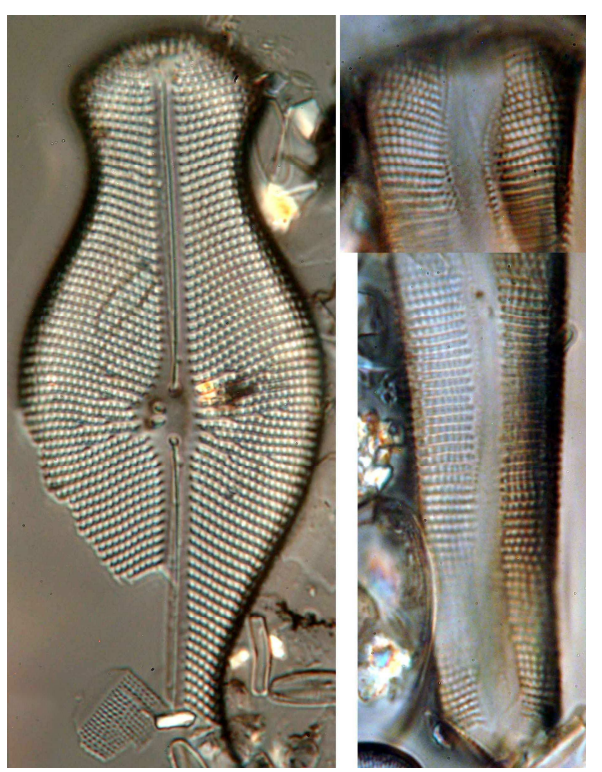

A Didymosphenia geminata egy édesvízi kovaalga faj, mely aljzathoz rögzült bentikus életmódot folytat (BLANCO \& ECTOR 2009; 1. ábra). Nagy mennyiségben képes kocsonyás anyagok (elsődlegesen poliszacharidok és fehérjék) kiválasztására, melyek hosszú, több centimétert is elérő nyéllé állhatnak össze (GRETz et al. 2007). Az egyes egyedek e kocsonyanyél segítségével rögzülnek az aljzathoz.

1. ábra. A Didymosphenia geminata fénymikroszkópos felvétele (Buczkó Krisztina felvétele) Fig. 1. Light microscopic photograph of D. geminata (photo by K. Buczkó) 


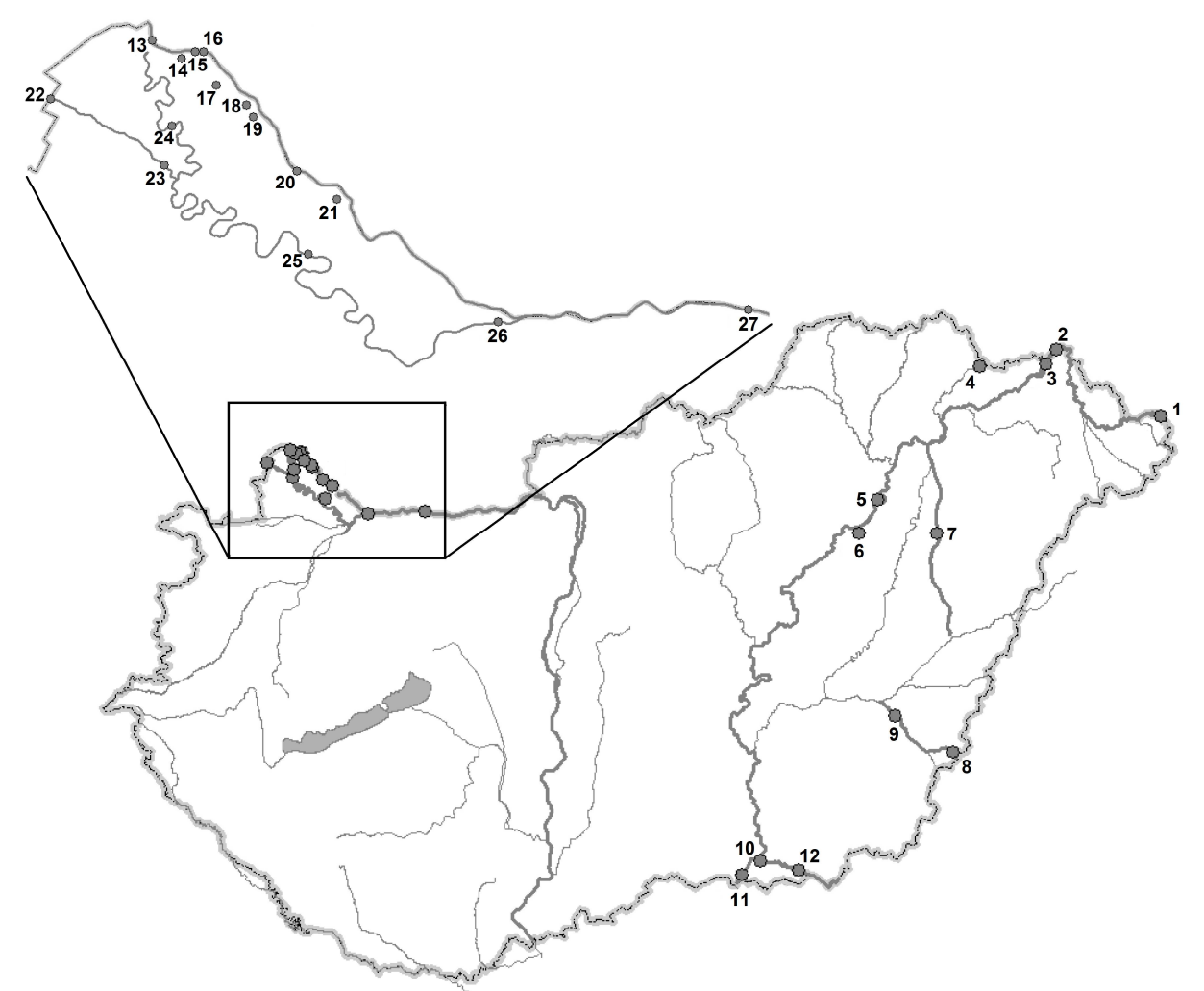

2. ábra. A Didymosphenia geminata magyarországi elterjedése

Fig. 2. The distribution of D. geminata in Hungary

A D. geminata eredeti elterjedési területe Észak-Amerika és Európa, azonban az elmúlt években egyre nagyobb ökológiai és gazdasági problémát okoz elsősorban az új-zélandi, argentínai és chilei tömeges megjelenése, így ezeken a helyeken invazív fajként tartják számon (KiLroy 2004, Kilroy et al. 2005, SPAUlding \& ElWELl 2007, BLANCO \& ECTOR 2009). Jelenléte hazai vizeinkben a 1960-1970-es évektől már kimutatható (BACKHAUS 1968), ugyanakkor rendszeresen csak a 2000-es évektől találták meg (PADisÁK et al. 2003, Ács et al. 2003, 2004, BuCZKó 2005, 2010, SzABó et al. 2005, T-KRASZnAI et al. 2014). Fontos kiemelni, hogy Magyarországon eddig csak szórványosan, kis egyedszámmal fordult elő (2. ábra, 1. táblázat).

Egészen az 1980-as évek végéig a $D$. geminata-t az alacsony vezetőképességű, oligotróf, hideg vizek (hegy- és dombvidéki víztípusok) indikátorfajának tartották (Hustedt 1930, Krammer \& LANGE-Bertalot 1997). Az elmúlt 25 év tapasztalatai alapján azonban egyértelművé vált, hogy a faj ökológiai toleranciája szélesebb: magas tápanyagtartalmú, eutróf alföldi vizekben, ill. hasonló jellegű antropogén hatásoknak jelentős mértékben kitett, gyorsabb sodrású patakokban is rendszeresen jelen van (KILROY 2004, SPAULDING \& ElWELl 2007, BlANCO \& ECTOR 2009, T-Krasznai et al. 2014). Tömeges elszaporodása esetén a sejtek által kiválasztott kocsonyás polimerháló akár több centiméter vastag és több kilométer hosszú szőnyeget is alkothat az aljzaton (SPAULDING \& ELWELL 2007, BLANCO \& ECTOR 2009). A tömeges előfordulás az adott terület táplálékhálózatának felborulásához vezethet, csökkentve több élőlénycsoport (vízi makrogerinctelenek, halak) élő- és szaporodóhelyeit, alapjaiban veszélyeztetve a közösség biodiverzitását (MUNDIE \& CRABTREe 1997, JónSSON et al. 2000, BROWn 2008, BlAnCo \& ECTOR 2009). 
1. táblázat. A Didymosphenia geminata ismert előfordulási helyei Magyarországon (a táblázat az Országos Környezetvédelmi Információs Rendszer irataiban használt struktúrát követi) Table 1. The known localities of D. geminata in Hungary

\begin{tabular}{|c|c|c|c|c|c|}
\hline & \multirow[b]{2}{*}{ Előfordulás helye } & \multicolumn{4}{|c|}{ Hidromorfológiai típus } \\
\hline & & 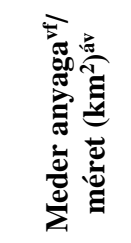 & 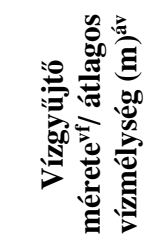 & 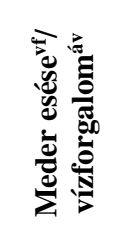 & 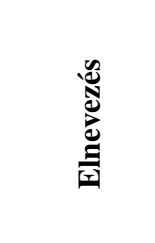 \\
\hline 1 & Tisza: Tiszabecs & durva & nagy & kicsi & $\begin{array}{l}\text { közepes } \\
\text { folyó }\end{array}$ \\
\hline 2 & Tisza: Záhony & $\begin{array}{l}\text { közepes- } \\
\text { finom }\end{array}$ & $\begin{array}{l}\text { nagyon } \\
\text { nagy }\end{array}$ & kicsi & nagy folyó \\
\hline 3 & Tisza: Zemplénagárd & $\begin{array}{l}\text { közepes- } \\
\text { finom }\end{array}$ & $\begin{array}{c}\text { nagyon } \\
\text { nagy }\end{array}$ & kicsi & nagy folyó \\
\hline 4 & Bodrog: Sátoraljaújhely & $\begin{array}{l}\text { közepes- } \\
\text { finom }\end{array}$ & nagy & kicsi & $\begin{array}{l}\text { közepes } \\
\text { folyó }\end{array}$ \\
\hline 5 & Tisza: Tiszakeszi & $\begin{array}{l}\text { közepes- } \\
\text { finom }\end{array}$ & $\begin{array}{l}\text { nagyon } \\
\text { nagy }\end{array}$ & kicsi & nagy folyó \\
\hline 6 & Egyeki Holt-Tisza: Egyek & kicsi & sekély & állandó & holtmeder \\
\hline 7 & Keleti-föcsatorna: Balmazújváros & $\begin{array}{l}\text { közepes- } \\
\text { finom }\end{array}$ & nagy & kicsi & $\begin{array}{l}\text { közepes } \\
\text { folyó }\end{array}$ \\
\hline 8 & Fekete-Körös: Sarkad & $\begin{array}{l}\text { közepes- } \\
\text { finom }\end{array}$ & nagy & kicsi & $\begin{array}{l}\text { közepes } \\
\text { folyó }\end{array}$ \\
\hline 9 & Kettős-Körös: Mezőberény & $\begin{array}{l}\text { közepes- } \\
\text { finom }\end{array}$ & $\begin{array}{c}\text { nagyon } \\
\text { nagy }\end{array}$ & kicsi & nagy folyó \\
\hline 10 & Maros: Szeged & $\begin{array}{l}\text { közepes- } \\
\text { finom }\end{array}$ & $\begin{array}{c}\text { nagyon } \\
\text { nagy }\end{array}$ & kicsi & nagy folyó \\
\hline 11 & Tisza: Tiszasziget & $\begin{array}{l}\text { közepes- } \\
\text { finom }\end{array}$ & $\begin{array}{c}\text { nagyon } \\
\text { nagy }\end{array}$ & kicsi & nagy folyó \\
\hline 12 & Maros: Makó & $\begin{array}{l}\text { közepes- } \\
\text { finom }\end{array}$ & $\begin{array}{l}\text { nagyon } \\
\text { nagy }\end{array}$ & kicsi & nagy folyó \\
\hline 13 & Duna: Rajka & durva & Duna méret & kicsi & folyam \\
\hline 14 & Duna, Helenai-ág: Dunakiliti & durva & Duna méret & kicsi & folyam \\
\hline 15 & $\begin{array}{l}\text { Duna: Dunakiliti, fenékküszöb } \\
\text { felett }\end{array}$ & durva & Duna méret & kicsi & folyam \\
\hline 16 & $\begin{array}{l}\text { Duna: Dunakiliti, fenékküszöb } \\
\text { alatt }\end{array}$ & durva & Duna méret & kicsi & folyam \\
\hline 17 & Duna, Szigeti-ág: Doborgazsziget & durva & Duna méret & kicsi & folyam \\
\hline 18 & Duna: Cikolasziget & durva & Duna méret & kicsi & folyam \\
\hline 19 & Duna: Dunasziget & durva & Duna méret & kicsi & folyam \\
\hline 20 & Duna: Dunaremete & durva & Duna méret & kicsi & folyam \\
\hline 21 & Duna, Ásványi ág & durva & Duna méret & kicsi & folyam \\
\hline 22 & Lajta: Hegyeshalom & durva & nagy & kicsi & $\begin{array}{l}\text { közepes } \\
\text { folyó }\end{array}$ \\
\hline 23 & Lajta: Mosonmagyaróvár & durva & nagy & kicsi & $\begin{array}{l}\text { közepes } \\
\text { folyó }\end{array}$ \\
\hline 24 & Mosoni-Duna: Feketeerdő & durva & közepes & kicsi & kis folyó \\
\hline 25 & Mosoni-Duna: Mecsér & durva & nagy & kicsi & $\begin{array}{l}\text { közepes } \\
\text { folyó }\end{array}$ \\
\hline 26 & Mosoni-Duna: Vének & durva & Duna méret & kicsi & folyam \\
\hline 27 & Duna: Komárom & $\begin{array}{l}\text { közepes- } \\
\text { finom }\end{array}$ & Duna méret & kicsi & folyam \\
\hline
\end{tabular}




\section{Haematococcus pluvialis Flotow}

A Haematococcus pluvialis zöldalga sejtek jellemzően gömb, vagy ellipszis alakúak, átlátszó, kiterjedt nyálkás sejtfallal (JoHN et al. 2002) (3. ábra). A vegetatív sejtek ostorosak, színük a domináns fotoszintetikus pigmentek miatt általában zöld (3. ábra A). A vegetatív sejtek kedvezőtlen körülmények között mozgásképtelen, vastag sejtfalú, a megváltozott színanyag-összetétel miatt piros színủ aplanospórává, más néven cisztává alakulnak (KOBAYASHI \& OKADA 2000, JoHN et al. 2002, FÁBREGAS et al. 2003, EvENS et al. 2008) (3. ábra B).

A Haematococcus pluvialis kozmopolita zöldalga faj (РRостоR 1957, JoHn et al. 2002). Érdekessége, hogy rendszerint tömegesen fordul elő időszakos kisvizekben, élénkpiros színűre színezve azokat (JoHN et al. 2002). Az időszakos vizekhez kötött jellegéből adódóan hazai elterjedésére vonatkozóan jobbára csak szórványos adatokkal rendelkezünk (2. táblázat; FELFÖLDY 1985, BoRICS et al. 1998, BÁCSI ex verb. 2014), ugyanakkor hazai előfordulását már Kol Erzsébet, egykori híres algakutatónk is leírta. A néphagyományban „véres vizek”-ként említett vízszíneződésért általában a $H$. pluvialis felelős. E jelenség itatókban, madárfürdetőben, a legkisebb esővízzel töltött mélyedésekben, temetői vázákban is előfordulhat (РRостоR 1957, JoHN et al. 2002).

2. táblázat. A Haematococcus pluvialis ismert hazai előfordulási helyei Table 2. The known localities of H. pluvialis in Hungary

\begin{tabular}{ll}
\hline & Előfordulás helye \\
\hline Balaton & jégen gyűjtött víz \\
Tihany & partmenti litotelmák; kerítésen lévő cserépmélyedésben \\
Fertő & - \\
Duna & - \\
Budapest & szökőkút, épületek vázai, stb. \\
Pécsely-patak & \\
Szakadékvölgyi kőhíd & litotelma \\
Budapest & vízmű \\
Baja & laboratóriumi akvárium \\
Debrecen & laboratóriumi Erlenmeyer-lombik \\
Debrecen & erkélyen vízgyújtő tál \\
\hline
\end{tabular}

A H. pluvialis a jelen pillanatban ismert leggazdagabb természetes forrása az asztaxantin nevű karotinoid pigmentnek, amit az egyik legerősebb antioxidánsként tartanak számon (HoRváth 2015). Az asztaxantin termelés első és egyik legfontosabb lépése során a zöld színű vegetatív sejteket stresszhatásnak teszik ki, melynek következtében azok karotinoidokban gazdag, piros színű cisztákká alakulnak (EVENS et al. 2008). A karotinképzést és -felhalmozást kiváltó stressz igen sokféle lehet: erős, vagy éppen nagyon gyenge fényklíma (STEINBRENNER \& LINDEN 2001, KATSUDA et al. 2006, Li et al. 2010); a tápanyag mennyisége és minősége (FÁBREGAS et al. 2003, OROSA et al. 2005, KANG et al. 2006, 2007, 2010), valamint a sótartalom és pH megváltoztatása (HATA et al. 2001, SARADA et al. 2002). 
B-BÉRES et al. (2016) - Kitaibelia 21 (1): 148-158.

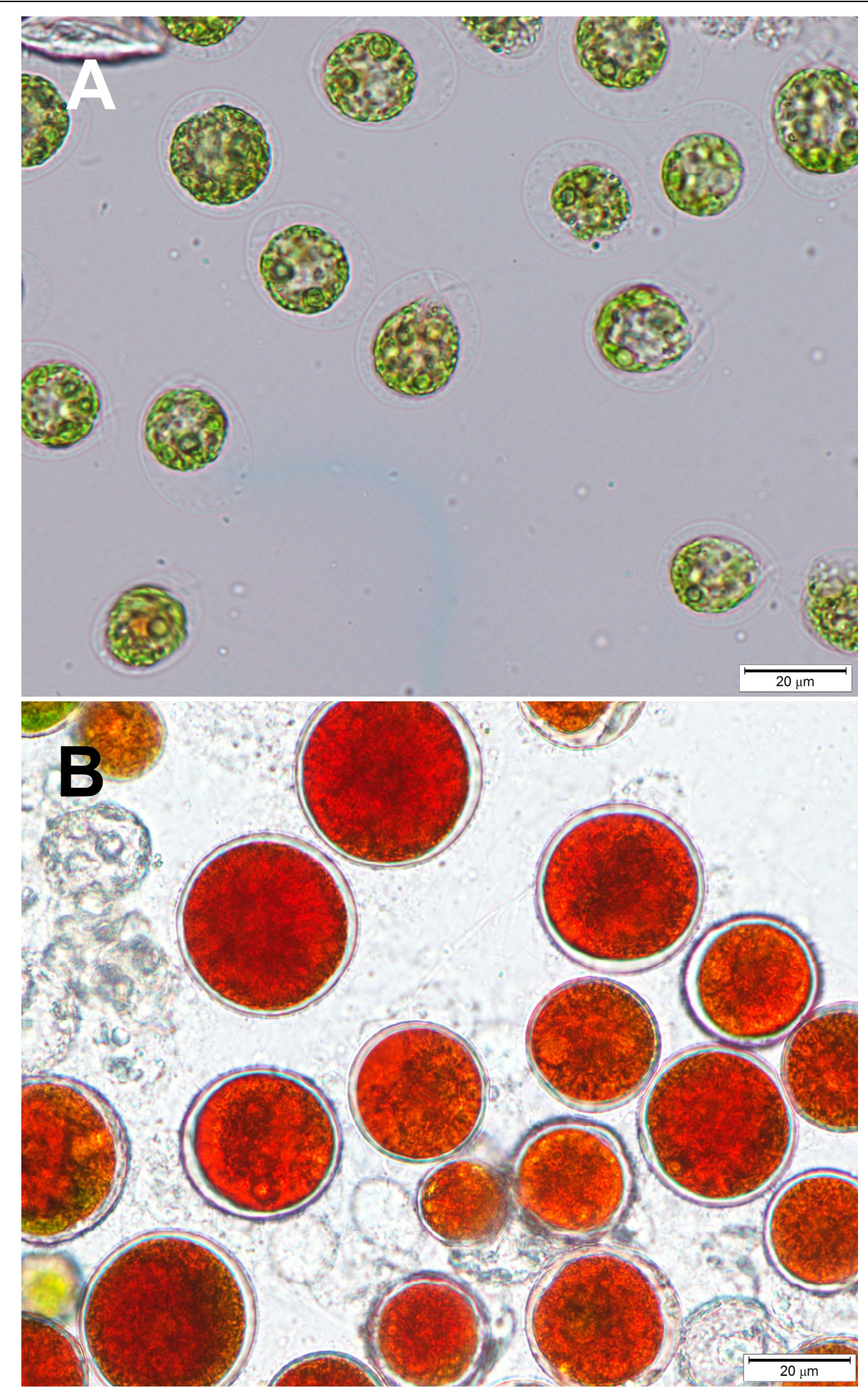

3. ábra. (A) A Haematococcus pluvialis vegetatív sejtjei és (B) ciszta állapota (Bácsi István felvételei)

Fig. 3. (A) Vegetative cells and (B) cysts of H. pluvialis (photos by I. Bácsi) 
Az ipari mértékben előállított asztaxantint az élelmiszer-, gyógyszer-, kozmetika-, valamint a takarmányipar is hasznosítja (LORENZ \& CYSEWSKI 2000, CHOI et al. 2011, LENNIKOV et al. 2012). Az asztaxantin védelmet nyújt az UV károsító hatásával szemben, valamint jelentős gyulladáscsökkentő, ill. immunerősítő hatása van (KOBAYASHI \& OKADA 2000). Ez utóbbi magyarázza a széleskörű felhasználási lehetőségeit a humánegészségügy területén is (LORENZ \& CYSEWSKI 2000, FÁBREGAS et al. 2001, Domínguez-BOCANEGRA et al. 2007, CHOI et al. 2011, TOCQUin et al. 2012). Az állati takarmányozásban pedig elsődlegesen mint színezőanyagot használják (pl. lazachús és tojássárga színintenzitásának növelése - LORENZ \& CYSEWSKI 2000).

\section{Prymnesium parvum N. Carter}

A Prymnesium parvum (aranyalga) mixotróf anyagcserét folytató Haptophyta algafaj (LARSEN et al. 1997). Két azonos hosszúságú mozgékony ostora a mozgásban, a harmadik, rövidebb merev középső ostor (haptonéma) pedig feltehetően a táplálékszerzésben, és/vagy a sejt rögzülésében játszik szerepet (LARSEN et al. 1997) (4. ábra). Jellegzetessége a két aranysárga színű színtest, mely klorofill mellett nagy mennyiségben tartalmaz járulékos színanyagokat is, mint például fukoxantint és karotinoidokat. Tömeges megjelenésekor a faj járulékos pigmentjeinek köszönhetően intenzív sárgára „színezi” a vizet (innen ered az aranyalga név; LARSEN et al. 1997).

A P. parvum más algafajokkal ellentétben pl. a tápanyag-tartalom csökkenésével, a fényintenzitás, a sótartalom, vagy a vízhőmérséklet hirtelen megemelkedésével szaporodhat el tömegesen (vízvirágzás), amely során mérgező vegyületeket (toxinokat) bocsáthat a víztérbe (GRANÉLI et al. 2012, RoELKE et al. 2016). Ezen allelopatikus hatású vegyületeknek köszönhetően nemcsak a planktonikus algaközösség taxonómiai összetétele változhat meg (például más toxintermelő fajok egyedszámának, ill. toxintermelő képességének megváltozása), hanem a zooplankton közösségeké, ill. a makroszkopikus gerinctelen állatoké is. Ezek a változások pedig már a teljes táplálékhálózatot negatívan befolyásolhatják (GRANELI et al. 2007).

A faj elsődlegesen a sós-, ill. brakkvizekben fordul elő (EDVARDSEN et al. 1998); az elmúlt 30 évben azonban egyre több alkalommal jelentették hazai, dél-keletmagyarországi kisebb tavakból. Az előfordulási helyek közös jellemzője a nagy sótartalom, magas vezetőképesség (2500-15000 $\left.\mu \mathrm{S} \mathrm{cm}^{-1}\right)$, lúgos $\mathrm{pH}(8,3-10)$, az agyagos-szikes jelleg és a közepes vízmélység (2-5 m). Ennek megfelelően hazai előfordulása elsősorban agyagbánya tavakban valószínűsíthető (VASAS et al. 2007, 2012, VASAS 2014) (4. ábra, 3. táblázat).

A $P$. parvum tömeges elszaporodásakor kibocsátott toxinok igen komoly gazdasági problémákat (például halpusztulást) okozhatnak (VASAS et al. 2007, 2012, GRANÉLI et al. 2012). Mivel a toxikus anyagcseretermékek igen sokfélék lehetnek, a kifejtett hatás is igen összetett (VASAS et al. 2007, 2012): antibakteriális, májkárosító, idegrendszert károsító, vagy sejtkárosító (TomAS et al. 2002, VASAS et al. 2012). Fontos hangsúlyozni, hogy a vízi gerincesek közül elsődlegesen a halakra van közvetlen hatással (SHILO 1981). 


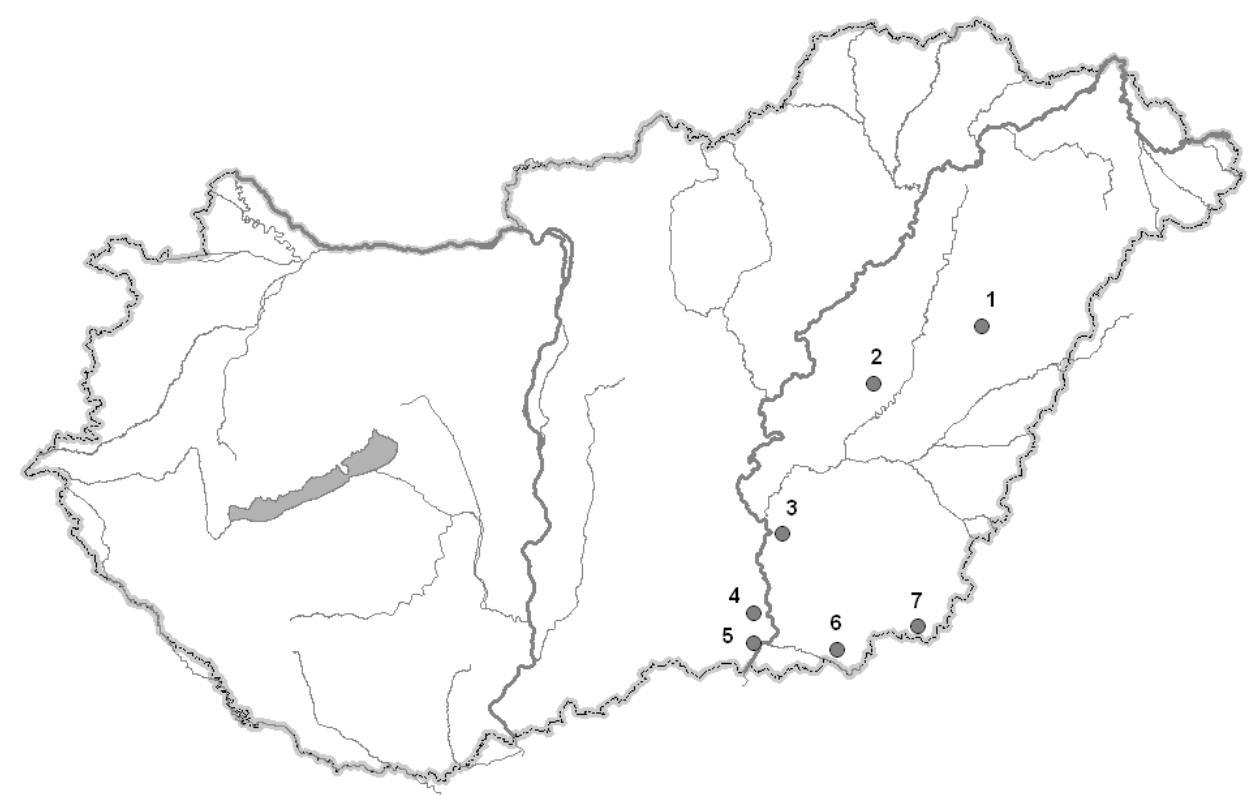

4. ábra. A Prymnesium parvum magyarországi elterjedése

Fig. 4. The distribution of P. parvum in Hungary

3. táblázat. A Prymnesium parvum előfordulási helyei Magyarországon Table 3. The known localities of $P$. parvum in Hungary

\begin{tabular}{llccc}
\hline & \multicolumn{2}{c}{ Előfordulás helye } & \multicolumn{2}{c}{ Hidromorfológiai típus } \\
\cline { 3 - 5 } & & Geokémiai jellege & Méret & Vízforgalom \\
\hline $\mathbf{1}$ & Téglagyári Öreg-tó: Hajdúszoboszló & meszes & kicsi & állandó \\
$\mathbf{2}$ & Halastó: Kisújszállás & meszes & kicsi & állandó \\
$\mathbf{3}$ & Pankota-tó: Szentes & agyagos-szikes & kicsi & állandó \\
$\mathbf{4}$ & Kovács-tó: Sándorfalva & agyagos-szikes & kicsi & állandó \\
$\mathbf{5}$ & Téglagyári-tavak: Szeged & agyagos-szikes & kicsi & állandó \\
$\mathbf{6}$ & Téglagyári Dögös-tó: Makó & agyagos-szikes & kicsi & állandó \\
$\mathbf{7}$ & Horgásztó: Battonya & agyagos-szikes & kicsi & állandó \\
\hline
\end{tabular}

Az első év pozitív tapasztalatait alapul véve az Algológus Fórum a jövőben minden évben megtartja az „Év Algája” internetes szavazást, remélve, hogy jelen algavilágot bemutató közönség-szavazás egyre több fórumon jelenik majd meg, hozzájárulva a mikroszkopikus világ hazai, szélesebb társadalmi réteget lefedő népszerüsítéséhez.

\section{Köszönetnyilvánítás}

Ezúton szeretnénk köszönetet mondani minden kollégánknak, akik hozzájárultak az „Év Algája” kezdeményezés elindításához, illetve jelen munka elkészítéséhez. A térképek elkészítésében való közreműködést köszönjük Matkó Andreának, Holló Ildikónak, Nagy Katalinnak, Vasas Gábornak, Kovács Krisztiánnak és Török Ferencnek. 


\section{Irodalomjegyzék}

Ács É., SzABó K., Kiss K. T. \& HindÁK F. (2003): Benthic algal investigations in the Danube river and some of its main tributaries from Germany to Hungary. - Biologia 58: 545-554.

BACKHAUS D. (1968): Ökologische Untersuchungen an Aufwuchsalgen der obersten Donau und ihrer Quellflüsse, III. Die Algenverteilung und ihre Beziehung zur Milieuofferte. - Archiv für Hydrobiologie 34: 130-149.

BlANCO S. \& ECTOR L. (2009): Distribution, ecology and nuisance effects of the freshwater invasive diatom Didymosphenia geminata (Lyngbye) M. Schmidt: a literature review. Nova Hedwigia 88 (2-3): 347-422.

BRown C. A. (2008): Changes in the composition and growth of invertebrates in rocky mountain streams due to blooms of the nuisance diatom Didymosphenia geminata. - NABS 56th Annual Meeting (25-28 May, 2008), Salt Lake City.

Borics G., Fehér G. \& SCHMidT A. (1998): Hydrochemical data for mass occurence of Haematococcus pluvialis (Chlorophyceae) - Biologia Bratislava 53: 495-497.

BuczKó K. (2010): Sixteen years of diatom monitoring of Szigetköz region of Danube - An illustrated Diatom Checklist of the Szigetköz region, Hungary. - In: KuSBER W. H. \& JAHN R. (eds), Abstracts of the 4th Central European Diatom Meeting, 12-14. March 2010. Reichenau/Bodensee, Botanical Garden and Botanical Museum Berlin-Dahlem, pp. 9-10.

CARTER N. (1937): New or interesting algae from brackish water. - Archiv für Protistenkunde 90: 1-68.

Choi Y-E., Yun Y-S., PARK J. M. \& YANG J-W. (2011): Determination of the time transferring cells for astaxanthin production considering two-stage process of Haematococcus pluvialis cultivation. - Bioresource Technology 102: 11249-11253.

Domínguez-Bocanegra A. R., Ponce-Noyola T. \& Torres-Munoz J. A. (2007): Astaxanthin production by Phaffia rhodozyma and Haematococcus pluvialis: a comperative study. Applied Microbiology Biotechnology 75: 783-791.

Edvardsen B. \& PAasche E. (1998): Bloom dynamics and physiology of Prymnesium and Chrysochromulina. - In: Anderson D. M., Cembella A. D. \& HallegraefF G. M. (eds), The Physiological Ecology of Harmful Algal Blooms. Springer Verlag, Heidelberg, pp. 193-208.

Evens T. J., NiedZ R. P. \& KiRKPATRICK G. J. (2008): Temperature and irradiance inpacts on the growth, pigmentation and photosystem II quantum yields of Haematococcus pluvialis (Chlorophyceae). - Journal of Applied Phycology 20: 411-422.

FÁBREgas J., OTERo A., MASEDA A. \& DomíngueZ A. (2001): Two-stage cultures for the production of Astaxanthin from Haematococcus pluvialis. - Journal of Biotechnology 89: 65-71.

FÁBREgAS J., DomínguEZ A., MASEDA A. \& OTERo A. (2003): Interactions between irradiance and nutrient availability during astaxanthin accumulation and degradation in Haematococcus pluvialis. - Applied Microbiology Biotechnology 61:545-551.

FELFölDY L. (1985): A zöldalgák Phytomonadina csoportjának kishatározója. - In: FELFöLDY L. (szerk.), Vízügyi Hidrobiológia 14. Országos Vízügyi Hivatal, Budapest, pp. 105-106.

Flotow J. von (1844): Beobachtungen über Haematococcus pluvialis. - Verhandlungen der Kaiserlichen Leopoldinisch-Carolinischen Deutschen Akademie der Naturforscher 12: 413606, 3 pls.

GranÉLI E., SALOMon P. S. \& Fistarol G. O. (2008): The role of allelopathy for harmful algae bloom formation. - In: Evangelista V., Barsanti L., Frassanito A. M., PAsSarelli V. \& Gualtieri P. (eds), Algal Toxins: Nature, Occurrence, Effect and Detection. NATO Science for Peace and Security Series A: Chemistry and Biology. Springer-Verlag, The Netherlands, pp. 159-178.

Granéli E., Edvardsen B., Roelke D. L. \& Hagström J. A. (2012):The ecophysiology and bloom dynamics of Prymnesium spp. - Harmful Algae 14: 260-270.

Gretz M. R., Riccio M. L., Kiemle S. N., Domozych D. S. \& Spaulding S. A. (2007): Didymosphenia geminata as a nuisance diatom: runaway stalk production results in mats withsignificant environmental impact. - Journal of Phycology 43 (Suppl.): 16.

Hata N., Ogbonna J. C., Hasegawa Y., Taroda H. \& Tanaka H. (2001): Production of astaxanthin by Haematococcus pluvialis in a sequential heterotrophic-photoautotrophic culture. - Journal of Applied Phycology 13: 395-402. 
HoRvÁth E. (2015): A Haematococcus pluvialis és az astaxanthin. - Szakdolgozat, Debreceni Egyetem, 48. pp.

Hustedt F. (1930): Bacillariophyta (Diatomeae). - In: PASCHER A. (ed.), Die Süsswasser-Flora Mitteleuropas 10 (ed. 2), Gustav Fischer, Jena, pp. 1-466.

John D. M., Whiтton B. A. \& Broок A. J. (2002): The Freshwater Algal Flora of the British Isles: An Identification Guide to Freshwater and Terrestrial Algae. - Cambridge University Press, Cambridge.

JónsSON G. S., JónsSON I. R., BJöRnSSON M., \& EinARSSON S. M. (2000): Using regionalization in mapping the distribution of the diatom species Didymosphenia geminata (Lyngb.) M. Schmidt in Icelandic rivers. - Verhandlungen der Internationalen Vereinigung für Theoretische und Angewandte Limnologie. 27: 340-343.

KANG C. D., AN J.Y., PARK T.H. \& Sim S. J. (2006): Astaxanthin biosynthesis from simultaneous N and $\mathrm{P}$ uptake by the green alga Haematococcus pluvialis in primary- treated wastewater. Biochemical Engineering Journal 31: 234-238.

KANG C. D., LEE J. S., PARK T. H. \& Sim S. J. (2007): Complementary limiting factors of astaxanthin synthesis during photoautotrophic induction of Haematococcus pluvialis: $\mathrm{C} / \mathrm{N}$ ratio and light intensity. - Applied Microbiology Biotechniology 74: 987-994.

KANG C. D., Han S. J., Choi S.P. \& Sim S. J. (2010): Fed-batch culture of astaxanthin-rich Haematococcus pluvialis by exponential nutrient feeding and stepwise light supplementation. - Bioprocess Biosystems Engineering 33: 133-139.

Katsuda T., Shimahara K., Shiraishi H., Yamagami K., RanjBar R. \& Katoh S. (2006): Effect of flashing light from blue light emitting diodes on cell growth and astaxanthin production of Haematococcus pluvialis. - Journal of Bioscience and Bioengineering 102: 442-446.

Kilroy C. (2004): A new alien diatom, Didymosphenia geminata (Lyngbye) Schmidt: its biology, distribution, effects and potential risks for New Zealand fresh waters. - NIWA Client Report CHC 2004-128, Christchurch.

Kilroy C., Snelder T. \& Sykes J. (2005): Likely environments in which the nonindigenous freshwater diatom, Didymosphenia geminata, can survive, in New Zealand. - National Institute of Water \& Atmospheric Research Ltd, Christchurch.

KoBAYASH M. \& OKADA T. (2000): Protective role of astaxanthin U.V.-B irradiation in the green alga Haematococcus pluvialis. - Biotechnology Letters 22: 177-181.

Krammer K. \& LANGe-Bertalot H. (1997): Bacillariophyceae 1. Teil: Naviculaceae. - In: EtTL H., Gerloff J., Heynig H. \& Mollenhauer D. (eds), Süßwasserflora von Mitteleuropa. Elsevier, Heidelberg, $876 \mathrm{pp}$.

LARSEN A. \& MEDLIN L. K. (1997): Inter- and intraspecific genetic variation in twelve Prymnesium (Haptophyceae) clones. - Journal of Phycology 33: 1007-1015.

LENNikov A., NoBuYoshi K. \& RISA FUKASE (2012): Amelioration of ultraviolet-induced photokeratitis in mice treated with astaxanthin eye drops. - Molecular Vision 18: 455-64.

Li Y., Sommerfeld M., CHEN F. \& Hu Q. (2010): Effect of photon flux densities on regulation of carotenogenesis and cell viability of Haematococcus pluvialis (Clorophyceae). - Journal of Applied Phycology 22: 253-263.

LORENZ R. T. \& CYSEWSKI G. R. (2000): Commercial potential for Haematococcus microalgae as a neutral source of astaxanthin. - Trends in Biotechnology 18: 160-167.

Sснмidt M. (1899): Plates 213-216. - In: Schmidt A. (ed.), Atlas der Diatomaceenkunde. Leipzig: R. Reisland.

Mundie J. H. \& CrabtreE D. G. (1997): Effects on sediments and biota of cleaning a salmonid spawning channel. - Fisheries Management and Ecology 4: 111-126.

Orosa M., Franqueira D., Cid A. \& Abalde J. (2005): Analysis and enhancement of asatxanthin accumulation in Haematococcus pluvialis. - Bioresource Technology 96: 373-378.

Padisák J., Borics G., Fehér G., Grigorszky I., Oldal V., Schmidt A. \& ZÁmbóné-Doma Zs. (2003): Dominant species, functional assemblages and frequency of equilibrium phases in late summer phytoplankton assemblages in Hungarian small shallow lakes. - Hydrobiologia 502: 157-168.

Proctor V. W. (1957): Some controlling factors in the distribution of Haematococcus pluvialis. - Ecology 38: 457-462. 
Roelke D. L., Barkoh A., Brooks B. W., Grover J. P., Hambright K. D., LaClaire II J. W., Moeller P. D. \& PATino R. (2016): A chronicle of a killer alga in the west: ecology, assessment, and management of Prymnesium parvum blooms. - Hydrobiologia 764: 29-50.

SARADA R., TRIPATHI U. \& RAVISHANKAR G. A. (2002): Influence of stress on astaxanthin production in Haematococcus pluvialis grown under different culture conditions. - Process Biochemistry 37: 623-627.

Shilo M. (1981): The toxic principles of Prymnesium parvum. - In: CARmichael W. W. (ed.), The Water Environment. Algal Toxins and Health. Plenum Press, New York, pp. 37-47.

SPAULDING S. A. \& ELWELL L. (2007): Increase in nuisance blooms and geographic expansion of the freshwater diatom Didymosphenia geminata. - Open-file report 2007-1425. U.S. Geological Survey, Denver, Colorado.

Steinbrenner J. \& Linden H. (2001): Regulation of Two Carotenoid Biosynthesis Genes Coding for Phytoene Synthase and Carotenoid Hydroxylase during Stress-Induced Astaxanthin Formation in the Green Alga Haematococcus pluvialis. - Plant Physiology 125: 810-817.

Szabó E. K., KISS K. T., TABA G. \& Ács É. (2005): Epiphytic diatoms of the Tisza River, Kisköre Reservoir and some oxbows of the Tisza River after the cyanide and heavy metal pollution in 2000. - Acta Botanica Croatica 64: 1-46.

T-Krasznai E., B-Béres V., KóKai Zs., BuczKó K., Balogh Cs. \& TöröK P. (2014): Adatok kilenc adventív, vagy invazív alga hazai előfordulásához. - Kitaibelia 19: 11-21.

TOCQUiN P., FRATAMICo A. \& FRANCK F. (2012): Screening for a low-cost Haematococcus pluvialis medium reveals an unexpected impact of a low N/P ratio on vegetative growth. - Journal of Applied Phycology 24: 365-373.

Tomas C. R., Glass J., RalPh J. \& Lewitus A. (2002): Blooms of the ichthyotoxi C flagellate Prymnesium parvum in U.S. waters: an emerging or a perennial problem? - Harmful Algae 1(369370). p. 6.

VASAS G. (2014): Algavirágzások környezetterhelése és toxinjainak variabilitása. - MTA doktori értekezés tézisei, $34 \mathrm{pp}$

VAsas G., Borics G., MiKóné-Hamvas M., NAgy-László Zs., Bácsi I. \& Borbély Gy. (2007): Prymnesium parvum (Carter) algavirágzás és halpusztulás a hajdúszoboszlói Öregtavon, az első toxikus eukarióta algavirágzás észlelése Magyarországról. - Hidrológiai Közlöny 87: 183-185.

VASAs G., M-Hamvas M., Borics G., Gonda S., MáthÉ Cs. \& NAGY-LÁszló Zs. (2012): Occurrence of a toxic Prymnesium parvum bloom with high protease activity is related to fish mortality in Hungarian ponds - Harmful Algae 17: 102-110.

\section{Hivatkozott világháló oldalak}

[1] Anonym. (2016): Algológus Fórum. http://hungarian-phycologist.blogspot.hu (Hozzáférés: 2016. 01. 16.)

[2] BuczKó K. (2005): Benthic diatoms. Phytobenthos.

http://www.szigetkozi-monitoring.hu/konferencia_2005/buczko_index_uk.htm (Hozzáférés: 2016. 01. 16.)

Beérkezett / received: 2016. 01. 17. • Elfogadva / accepted: 2016. 05. 01. 